\title{
WHAT OUR READERS THINK
}

As Episodes prepares for its transfer in July to the U.S.A. (see announcement below), a little public introspection may be in order, hased on the returns from the survey of our readers eirculated with the last issue. This is a convenient time to restate the overall guidelines that govern our content and to offer a few suggestions to the next editorial team.

Episodes is first and foremost the "flagship" of the International Union of Geological Sciences, and its content must, therefore, reflect the very broad concerns and activities of IUGS. This is done through refereed articles and state-ofthe-art reviews, as well as in the many conference and news reports, book reviews and other regular features. We report on new discoveries and developments in earth science, on regional and international projects, within IGCP and ILP for example, on important decisions of the IUGS Commission on Stratigraphy, the international authority for setting stratigraphic standards, as well as on such diverse topics as fossil aquifers, stone technology, UN activities in earth science, global change and even some aspects of the mining and oil industries.

However much one may dislike the organizational aspects of science, very few of us can avoid them. Accordingly, Episodes reviews from time to time the structure and management of the earth sciences, not only under the aegis of IUGS but also through international projects, intergovernmental programs, national and regional associations, or simply through conferences and working commissions.

The return on the Episodes Readership Survey so far has

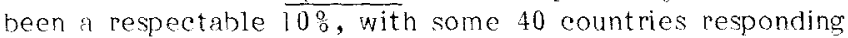
and most replies coming from the U.S.A., Canada, F.R.G., the U.K. and Australia where large numbers of subscribers live. It is naturally pleasant to learn that over $75 \%$ of respondents regard Episodes as useful and timely and that nearly $90 \%$ find the present mix of scientific and nonscientific information about right. Of course, if they did not presumably they would cancel their subseriptions: Yore than $70 \%$ of respondents say they read over half of earh issue. Among the regular features, most respondents (72: rato the articles as most useful and the personal profiles and lists of training courses least useful. Only $2 \%$ of respondents discard their copies after reading: nearly half circulate their copies or put them in their library for others to use.

lost respondents $\left(45^{\circ}\right)$ work in research, in teaching $(26 \%)$ in administration $\left(18 \frac{\circ}{\circ}\right)$ and $48 \%$ work for universities, $21 \%$ for government, $16 \frac{9}{0}$ as consultants and $11 \frac{8}{8}$ in industry. This is a similar breakdown to that determined in an earlier reader survey not long atter the launching of Episodes in 1978 by the late W.W. Hutchison. Our current distribution for regular issues is about 2700 copies, but since most go to institutional addresses, the readership is certainly lamer. Episodes is sent to 149 countries and territories by direct airmail or airspeeded post outside North America. Direct support from Unesco and IUGS ensures regular delivery to 300 institutions in developing countries.

It is probably impossible to meet all the demands of such a broad and diverse readership. Some respondents would like to see more on "soft-rock" geology, biostratigraphy and paleontology, while others want less on these topics. Wany would prefer to see more information on applied aspects of geoscience such as industrial minerals, groundwater, and nuclear waste disposal, but others would prefer to see more on igneous and metamorphic rocks, on the Precambrian, and on economic geologv. Quite a few respondents suggested that Episodes should regularly review the progress of geology on a country by country basis. There were suggestions, too, for listings of opportunities for academic exchanges, international job vacancies, sources of funding for international projects, and of eurrent IGCP and ICL projects.

Having been more or less tied to our present style and policy for some time now - by technology, money or even sheer inertia - we take this opportunity to state some of our own preferences. We would like to see a more easily readable typestyle, a more open page format, and better reproduction of graphics and photographs. We would also prefer more information on international projects, and more on the geology of Arab nations, the Soviet Union, Central America and the Caribbean, and Southeast Asia, especially by geologists living and working in these regions. Given the right finances, new technology will make the former readily attainable. Augmenting the inflow of information across linguistic and political boundaries will, however, not be so easy to accomplish. But then we would not like to see the new editor and his staff lack tough challenges!

IN THE JUNE ISSUE...

To mark the occasion of the 28 th International Geological Congress in Washington, D.C., the June issue of Episodes will highlight the work of IUGS.

Copies will be distributed to all registrants attending the Congress.

A Portrait of IUGS Proterozoic Glaciations

A Standard for the Pragian Stage

rectonics in Eastern Asia

$\Delta \mathrm{N}]$

The IUGS Global Stratigraphic Chart

\section{EPISODES IS MOVING}

The next (June 1989) issue will be the last to be produced in Ottawa. After that, the Episodes office will be based at the U.S. Geological Survey in Reston, Virginia, from where it will continue to function under IUGS policy. Dr. John Aaron, currently Chairman of the IUGS Advisory Board on Publications, will be the new editor. As of July 1, 1989, the address for all communications will be:

Episodes

P.O. Box 919

Herndon, VA 22070 , U.S.A. 